\title{
Mimarlık Eğitiminde Bütünleşik Eğitim Deneyimi ve Müfredat Önerisi
}

\author{
Doç. Dr. Serdar TOKA \\ Mardin Artuklu Üniversitesi \\ Mühendislik-Mimarlık Fakültesi \\ serdartoka@gmail.com \\ ORCID: 0000-000-8183-2690
}

\begin{abstract}
öz
Postyapısalcılık ile birlikte kuramsal alanda üzerine sıkça tartısmaların yürütüldüğü disiplinlerarası yaklaşım, uzmanlık sınırlarının eridiği günümüzde eğitim alanında da önem kazanmaktadır. Konstrüktivizm akımı ve Bauhaus okulundan itibaren sanat, mimarlık ve mühendislik üretim ve eğitim pratiklerinin bir arada yürütülmesi, disiplinlerarası yaklaşım olarak görülebilir. H.H. Jacobs'ın tartıştığı interdisipliner eğitim müfredat modelleri ise, hem kuramsal tartışma alanı yaratmakta hem de uygulama örnekleri ortaya koymaktadır. Bu çalışmada, mimarlık bölümünde Mimari Anlatım Teknikleri dersi ile Kültür ve Sanat Tarihine Giriş derslerinin bütünleşik eğitim modeline dayalı olarak yürütülmesinden çıkarılan sonuçlar değerlendirimiş ve bu deneyimden hareketle lisans düzeyinde mimarlık bölümü için sekiz dönemi içeren bütünleşik müfredat önerisi getirilmiştir. Bütünleşik eğitim, kuramsal ve uygulamalı derslerin birbiriyle etkileşimlerinin maksimum düzeye çıkarılarak geçişimli yürütülmesi pratikleri olarak tanımlanabilir. Bu modelde kuramsal, teknik dersler ve stüdyoların eşgüdümlü yürütülmesi mümkün olur. Öğrenciler tasarım projelerini edindikleri kuramsal, tasarımsal ve teknik arka planla yaparlar ve kuram derslerinde geri dönüşler sayesinde dersler arasında çok yönlü akışlar gerçekleşir. Bilgi ve tasarım pratikleri bütünleşir ve empatiyle çok yönlü anlama ve zihinsel esneklik desteklenir.
\end{abstract}

Anahtar Kelimeler: disiplinlerarası yaklaşım, sanat, mimarlık, müfredat.

Toka, S. (2021). Mimarlık Eğitiminde Bütünleşik Eğitim Deneyimi ve Müfredat Önerisi. ARTS: Artuklu Sanat ve Beşeri Bilimler Dergisi, 5, ss. 118-139. 


\title{
Integrated Education Experience and Curriculum Proposal in Architectural Education
}

\begin{abstract}
The interdisciplinary approach, which has become the subject of frequent discussions with the emerge of poststructuralism, has also gained importance in the field of education. Since the Constructivism movement and the Bauhaus school, integrated application of art, architecture and engineering production and education practices can be seen as an interdisciplinary approach. Interdisciplinary education curriculum models discussed by $\mathrm{H}$. H. Jacobs not only provide a space for theoretical discussion but also put forth examples of practical applications. In this study, the results obtained from courses of the Architectural Expression Techniques and Introduction to Culture and Art History, which were conducted with the application of the integrated education model in the Department of Architecture, were evaluated. Based on this experience, an integrated curriculum covering eight semesters has been proposed for undergraduate studies at the Department of Architecture. Integrated education can be defined as the practices of conducting theoretical and applied courses in a transitive manner by maximizing their interaction with each other. In this model, it is possible to conduct theoretical, technical courses and studios in a coordinated manner. Students produce their design projects with the theoretical, design and technical background they have acquired, and multi-directional flows occur between courses thanks to the feedbacks in theoretical courses. Knowledge and design practices are integrated, and versatile learning and mental flexibility are supported by empathy.
\end{abstract}

Keywords: interdisciplinary approach, art, architecture, curriculum. 


\section{arts $\mathbb{S}$}

\section{GíRiş}

Insanlar ve eleştiri okulları gibi, fikirler ve kuramlar da kişiden kişiye, durumdan duruma, bir dönemden diğerine seyahat eder. Kültürel ve entelektüel yaşam genellikle bu fikir dolaşımı ile beslenir ve çoğu zaman bu dolaşımla sürdürülür. İster kabul edilmiş biçimde veya bilinç dışı etkiyle olsun, ister yaratıcı ödünç alma ya da bütünüyle benimseme ile olsun fikirlerin ve kuramların bir yerden diğerine hareketi hem bir gerçek hem de entelektüel faaliyet için yararlı bir koşuldur. (Said, 1983, s. 226).

Postyapısalcılıkile birlikte sıkça tartışılan, her bir disipliner alanının diğer disipliner alanlarla yatay düzlemde ilişkiye geçmesini savunan disiplinlerarası yaklaşım; farklı disiplinlerin özerk ve temassız uzmanlık alanlarından çıkmasının ve yapısal ayrımların parçalanarak alternatif pratiklerin üretilmesinin önünü açar. Disipliner yaklaşım, her bir pratiğin uzmanlık alanına ait eğitim programınlarının kendi içinde kalarak kategorik olarak sistemleştirildiği modernizmden günümüze kadar gelen bir planlama modeli olarak uzun süre sürdürülmüştür. Mimarlık alanında ise, bu yaklaşım hakim anlayış olarak yerleşikliğini büyük ölçüde korur.

Bir disiplin olarak mimarlık ve mimarlık eğitimi nispeten yeni bir olgudur. Geleneksel toplumlardan modern toplumlara geçişin son yıllarına kadar mimarlık eğitimi, ustalardan öğrencilere bilgi ve beceri aktarım sürecine dayanmıştır. 19 ve 20. yüzyılda bilginin disiplinlere ayrılması ve meslekleşmesi yani yeni bilgi üretmek üzere kurumsal yapıların oluşturulması süreci sonunda, mimarlık eğitim sistemi birbirinden tamamen farklı ancak birbiriyle örtüşen dört farklı sisteme ayrımıştır. İlk kez Fransa'da organize, resmi mimarlık eğitimi fikri kurumsallaşmıştır. Almanya'da öğretim ile araştırma arasında bir bağlantı olduğu ve olması gerektiği ve üniversitelerde mimarlık eğitimi yoluyla bunun olanaklı olduğu fikri üzerinden kurumsallaşmaya gidilmiştir. Amerika'da ise bu iki ekol Britanya'dan miras kalan çıraklık sistemi ile sentezlenmiştir (Stevens, 2014, s. 1).

Farklı sistemlerin uygulanmasını savunan ve bunu yerleşik bir eğitim 
programlaması olarak sürdüren, bir nevi ekol niteliğinde olan bu sistemlerden sıyrılarak, mimarlık ve sanat eğitimini manifest nitelikte radikal şekilde değiştiren modelleme örnekleri ise avangart sanat ve mimarlık akımları içinden çıkmıştır. Hem mimarlık hem de sanat alanlarında, bütünleşik ve interdisipliner bir yaklaşımın yenilikçi bir programlama ve hayata dair bir duruş olarak sergilenmesinin örnekleri avangart akımlara kadar götürülebilir.

20. yüzyılın ilk yarısında Konstrüktivizm akımı ve Bauhaus okulunun çalışmalarına kadar götürülebilen interdisipliner eğitim pratikleri, sıkıca disiplinlere ayrılmış ve akademizm olarak adlandırılabilecek eğitim süreçlerine alternatif eleştirel yaklaşımlar olarak ele alınabilir.

Konstrüktivizm 1913 yılında Rusya'da Tatlin'nin önderliğinde ilk olarak mimarlıkta ortaya çıkar ve resim ve heykel alanlarında da yaygınlaşır. Modern malzemenin teknik analiziyle üretim sürecini ve mühendisliği estetik fikirlerle destekler, komünisł toplum düzenine hizmet edecek hayat ile iç içe geçmiş seri üretim ile sanatçının atölyesinden fabrikaya geçişini amaçlar. 1917 Devrimi'nden sonra akımın öncüsü sanatçılar, toplumsal gereksinimlere odaklanarak ve sanattan çok tasarıma dayanan yeni sanat öğretilerini devrim sonrası kurulan okullarda ve atölyelerde üretimi de içerecek şekilde hayata geçirirler.

VarvaraStepanova ve Aleksander Rodçenko 1922 tarihli BirinciKonstrüktivistler Çalışma Grubu Programı'nda: Sanayileşmiş malzemenin fonksiyonel kullanımı olan tektonika (tektonik); malzeme kullanım sürecinin düzenlenmesi olan konstruktsiya (konstrüksiyon) ve malzeme seçimi ve işlevsel hale getirilmiş malzeme olan faktura olmak üzere, pratik yapıların gerçekten bilimsel ve disiplinli bir şekilde yaratılmasında ustalık kazanmak için üç disiplin belirler. Konstrüktivizmin ilkelerinin belirlenmesinde öncü rol oynamış, devrim ilkelerini yaymak için kurulan sanat ve tasarım okullarında eğitimcilik yapan Aleksey Gan 1922 yllındaki Konstrüktivizm bildirisinde endüstriyel malzeme ve teknikleri yücelten ve geçmişle bağlarını kopartan yenilikçi bir öğreti ortaya koyar (Gan'dan aktaran Antmen, 2011, s. 111):

Tektonik, Komünizmin özelliklerine bağlı olarak, endüstriyel malzemelerin elverişli kullanımıyla ortaya çıkar ve şekillenir... Konstrüktivist, eğitimli bir Marksist olarak sanatı bütünüyle geride bırakmış ve endüstriyel malzeme konusunda kendini ileri düzeyde geliştirmiş bir kişi olmalıdır. Bu yolda Tektonik 


\section{arts}

onun deneysel ve pratik eylemlerinin zihinsel yönü olarak ona kılavuzluk edecektir. Faktura, malzemenin imal edilmesi sürecinin kendisidir. Malzemenin bir tarafının değil, bütününün imal süreci anlamına gelir.

Konstrüktivizm, 20. yüzyılın modern sanat akımları üzerinde büyük bir etkiye sahip olan Bauhaus ve De Stijl hareketleri gibi ana eğilimleri etkiler. Her ne kadar bir akım olarak yapıcılığı (konstrüksiyon estetiğini) öne çıkarsa da, Konstrüktivist akıma bağlı pratiklerde; sanatçı-mimar-mühendis üçlüsünün entegre üretim pratiklerini hayata geçirmesi söz konusudur. Yapısal tasarımların sanatçılar ile mimar ve mühendislerin ortak çalışmaları ile üretilmesi, bir eğitim modellemesi olmamakla birlikte, farklı disiplinleri bir araya getiren yenilikçi bir yaklaşım ve eğitim pratiği sergiler. Sosyalist gerçekçilik resmi tutum olarak benimsenince ve öncü sanatçıların Rusya' dan batıya göç etmesiyle ortadan kalkar (Sözen ve Tanyeli, 2011, s. 175).

Endüstri devrimi sonrası yeni "yapı" üretim pratiği geliştirmek için tüm tasarım disiplinlerinin yapıya hizmeł vermek üzere örgütlenmesi gerektiğini vurgulayan bir anlayışı hayata geçiren ve Walter Gropius tarafından Almanya' nın Weimar kentinde kurulan Bauhaus (yapım-evi) okulu, Gesamtkunstwerk (bütün sanat) anlayışına dayanan ve tüm sanat ve tasarım dallarının bir bütün olduğu görüşüyle sanat, zanaat, mimari ve teknolojiyi iç içe geçiren bir eğitim modeli olarak, 1919-1933 yılları arasında Nasyonal Sosyalist Alman İşçi Partisi tarafından kapatııncaya kadar varlığını sürdürmüştür. Sanat ve endüstriyi işlev ve toplumsal yarar bağlamında bir araya getiren bir eğitim merkezi olmayı arzular. Bauhaus'un temel düşüncesi ve disiplinlerarası deneysel müfredat ve yenilikçi öğretim uygulamaları, endüstriyel ürünlerin sanat ve estetik kaygı ile üretilmesini ve sanatı günlük hayatın içine sokan bir anlayışı sahiplenir. Uygulamalı eğitimin, atölyenin öncelikli olduğu modellemede usta-çırak ilişkisi esas alınır. Sanat ve zanaatı bütünleştirerek akademik eğitim sistemine alternatif sunar. Temel tasarım 1920'lerde modernizm ve Bauhaus okulunun temel öğretim konularından biri olarak mimarlık bölümlerinin günümüze kadar gelen kalıcı derslerinden bir haline gelmiştir. Gropius 1919 yılıdaki Weimer'daki Staatliches Bauhaus'un Programı başlıklı manifestosunda, eğitimin basamaklarına değinir: Her öğrencinin bir zanaat öğrenmek zorunda olduğu zanaat eğitimi, resim ve çizim eğitimi, bilim ve kuram eğitimi. Eğitim bölümlerini: Çıraklar için ders programı, kalfalar için ders programı ve genç ustalar için ders programı olmak üzere üç düzeye ayıır (Conrads, 1991, s.38). 1923 yllındaki Bauhaus'un Teorisi ve Örgütlenmesi başlıklı 
yazısında Weimar'daki okul hakkında şöyle söyler (Bayer, Gropius W. ve Gropius I.,1938, s. 24-25):

\begin{abstract}
Bir sanat akademisinin teorik müfredatı, bir sanat akademisinin pratik müfredatı ile birleştirildi. Sanat ve zanaat okulü, üstün yetenekli öğrenciler için kapsamlı bir sistemin temelini oluşturacaktı. İnanç şuydu: "Bauhaus, tüm yaratıcı çabanın koordine edilmesi, yeni bir mimaride sanat ve tasarımdaki tüm eğitimlerin birleştirilmesidir". Bauhaus'un uzak da olsa nihai hedefi kollektiftir. Yapısal ve dekoratif sanatlar arasında hiçbir engelin bulunmadığı sanat eseri; Yapı.
\end{abstract}

Bauhaus okulu sanatçı-mimar-usta pratiklerini bir araya getirerek eğitim modellemesi olarak iki temel grup disiplini kapsayan sistemli bir yaklaşım geliştirir: Werklehre (beceriöğrenimi) adı verilen el işçiliğinin pratik biçimde öğretildiği atölyeler ve Formlehre adı verilen kuramsal ve biçim yaratma sorununa eğilen atölyeler (Sözen ve Tanyeli, 2011 , s. 49). Bir mimarlık ve tasarım okulu olarak; çırak-kalfa-usta ilişkisini de bu sistemin içerisine yerleştirerek kuram, estetik ve uygulamayı bir araya getiren yenilikçi ve bütünleşik bir eğitim modeli ortaya koydukları söylenebilir. Ancak zamanla bu yenilikçi özelliklerini yitirirler; modernist stilin içinde kalarak, tasarım süreçlerinin giderek klişeleştiği ve kurallı hale gelip zihinsel esnekliği sınırlayan bir gelenekselleşmeye yönelirler.

Lisans veya yetişkin seviyesinden daha aşağı sınıfar ve yaş grupları için olmakla birlikte, okullarda uygulana gelen ve/veya üzerinde tartışıan müfredatların, modellerin avantajlı ve dezavantajlı yönlerine değinerek interdisipliner bütünleşik müfredat önerisinde bulunan Jacobs, disiplinlerarası kavramını; bir kavram, tema ya da problemin birden fazla disiplinin yöntem ve dilini kullanarak bütüncül bir yaklaşımla ele alınması olarak ele alır. Eğitim ve/veya ders içeriğinin belirlenmesinde: Disiplin temelli tasarım, paralel disiplin tasarımı, tamamlayıcı disiplin birimleri/dersleri, disiplinlerarası birimler/dersler, entegre gün modeli ve program tamamlama olmak üzere altı müfredat yaklaşımını değerlendirir. Disiplin temelli içerik tasarımda; okul günü boyunca ayrı zaman bloklarında ayrı konularla disiplinlerin katı bir şekilde ayrımına odaklanılır. Bütünleştirme için hiçbir girişimde bulunulmaz, aslında bundan kaçınıı. Paralel disiplin tasarımda; eğitmenler derslerini diğer disiplinlerde verilen konulara karşılık gelecek şekilde kendi disiplin alanlarında paralel bir şekilde işlerler. Tamamlayıcı disiplin birimleri veya dersleri tasarımında; belirli bir disiplinin bir temayı veya konuyu araştırmak için resmi birleşik bir derste diğer disiplinlerin eğitmenleri bir 
araya getirilir. Disiplinlerarası birimler/dersler tasarımında; haftalık, aylık, dönemlik vb. süreler için belirlenen bir ders ya da birimde okulun müfredatındaki tüm disiplinler bir araya getirilir. Entegre gün modeli; çocuğun dünyasında ortaya çıkan temalara ve sorunlara dayalı, tam günlük bir programdır. Devlet veya okul tarafından belirlenen müfredat içeriği yerine, çocuğun soruları ve ilgi alanlarına odaklanan organik sınıf yaşamına dayalı bir yaklaşımdır. Programı tamamlama yaklaşımı; disiplinlerarası çalışmanın en uç şeklidir. Öğrenciler okul ortamında yaşarlar ve müfredatı günlük yaşamlarından çıkarırlar (Jacobs, 1989, s. 13-24).

Interdisipliner yaklaşıma dayalı pratiklerden ve Jacobs'ın müfredat modellemelerinden (Jacobs, 1989, s. 13) yola çıkan bu çalışma; Mardin Artuklu Üniversitesi Mimarlık Fakültesi'nde 2019-2020 Güz Yarıylında Kültür Sanat Tarihine Giriş (KSTG) ve Mimari Anlatım Teknikleri (MAT) derslerinin bütünleşik yürütülmesi deneyimine dayanır. Tarihsel bir akış içerisinde iki farklı dersi aynı içerikte bir araya getirilerek bütünleşik eğitim modellemesini uygulamaya koyar. Bauhaus okuluyla sistemleşen temel tasarım dersiyle başlayan modern tasarım eğitimini de tartışmaya açar. Deneyimden yola çıkarak getirilen müfredat önerisi, yerleşik dört yıllık mimarlık programını; sanat, mimarlık ve kuram pratiklerinin ilişkiselliği üzerinden yenilikçi bir bakış açıyla güçlendiren manifest nitelikte bir yaklaşım sunar.

Günümüzde, her meslek alanında olduğu gibi mimarlık mesleği ve bu mesleğin öğretildiği eğitim programları çeşitli yeterlilik ve akreditasyon süreçlerine dâhil olmuştur. Ülkeden ülkeye ve kısmen de ülke içinde farkllıklar gösterebilen mimarlık eğitimi veren mimarlık programları arasında bir taraftan yenilikçi programları destekleyen bir taraftan da mevcut programların uluslararası standartlara uygunluğunu sağlayan çeşitli kuruluşlar faaliyetlerini yaygınlaştırmışlar ve akredite mimarlık programlarının geliştirilmesine teknik destek ve sonrasında denetim olanağı sağlamaktadırlar. 1940' da kuruluşundan itibaren; "Eğitim felsefelerinin veya uygulamalarının standardizasyonuna yönelecek koşullar yaratmamak veya koşulların yaratılmasına değil, daha ziyade bireysel okula özel koşullara uygun uygulamaların geliştirilmesini teşvik edecek koşullar yaratmak ve sürdürmek", misyonunu edinen The National Architectural Accrediting Board (NAAB), uluslararası akreditasyon sertifikası da veren Amerika Birleşik Devletleri'nde mimarlık programı alanında faaliyetlerini sürdüren bağımsız bir kuruluştur (The National Architectural Accrediting Board 
[NAAB], 2021). Yine, The European Association for Architectural Education (EAAE); Avrupa'da mimarlık okulları düzenlemek, mimarlık eğitiminin kalitesini artırmak için Avrupa mimarlık okulları ağı oluşturmak, tartışmaları, değişimleri ve ortak bir politikayı teşvik etmek misyonunu üstlenen, Avrupa Birliğine ait ülkelerle sınılı olmayan ve tüm Avrupa ülkelerinin katılabildiği üyeliğe dayalı kar amacı gütmeyen Belçika tescilli uluslararası bir kuruluştur. Çalıştay ve proje faaliyetleri ile uluslararası düzeyde mimarlık programlarını kısmen tartışmaya açmaktadır (The European Association for Architectural Education [EAAE], 2021).

Ulusal düzeyde faaliyet gösteren bu tür kuruluşlardan biri de ülkemizde Mimarlık Akreditasyon Kurulu adıyla 2006 yllından bu yana TMMOB Mimarlar Odası çatısı altında çalışmalarını yürüten MiAK'dır. Mimarlık Eğitimi Akreditasyon Derneği-MiAK olarak kuruluşu ise 2019 tarihinde onaylanmıştır. Mimarlık eğitiminin değerlendirme ve akreditasyon çalışmaları aracılığı ile geliştirilmesini ve böylece, daha iyi eğitilmiş ve kalitesi yükseltilmiş mimarlar yetiştirilerek toplum refahının ileri götürülmesini hedefleyen MiAK, mimarlık eğitimi veren mimarlık programlarının değerlendirilmesi ve akredite edilmesi sürecini ayrıntılı olarak düzenlemekte ve uygulamakta; kurumlara mimarlık eğitiminin değerlendirilmesi ile ilgili alanlarda teknik bilgi vermektedir. Akredite edilen kurumlar, bölümler ya da dereceler değil eğitim programlarıdır. Bir programın akredite edilebilmesi için, o programı tamamlamak üzere öğrencilerce izlenebilecek çeşitli seçeneklerin tümünün ilgili ölçütleri sağlaması gerekir. Ayrıca MIAK tarafından akredite edilmiş bulunan programlar, mimarlık alanında yükseköğretim düzeyindeki en az dört (4) yıllık lisans ve MiAK tarafından belirlenen lisansüstü programlardır.

Uluslararası ve ulusal alanda öne çıkan benzeri kuruluşların, mimarlık mesleği ve eğitiminde standart kalite ve uluslararası geçerliliği destekleyen hedefleri her ne kadar olumlu bir çaba gibi görünse de, eleştriel bir yaklaşımla olumsuz yönde etkileri olduğu da görülebilir. Mimarlık mesleği ve mimarlık eğitiminin süregiden tartışma konusunu olan teorik ve pratik arasındaki ayrışmadan kaynaklı bütünleşme problemini ele aldığı makalesinde Akgün; Bologna, MiAK vb. akreditasyon kıstaslarının tek tipleşmeyi desteklediğini, farklı eğitim modellerinin oluşmasına dolaylı olarak engel

1 http://miak.org. 2017 de başlayan MiAK akreditasyon başvurusunun Ağustos 2020 tarihi itibariyle üniversiteler ve programları bazında listesine: http://miak.org/index.cfm? sayfa=okullar adresinden ulaşllabilir. 


\section{arts $=$}

olduğunu, farklı öncelikleri ve programları olan mimarlık okulları sayesinde mimarlık disiplininin farklı alanlarıyla bütünleşme imkânının daha fazla olacağını ileri sürer (Akgün, 2016, s. 10-11).

Bu kuruluşlar bünyesinde yürütülen faaliyetlerin, bu makale kapsamında önerdiğimiz müfredat programını destekler nitelikte misyonlar edindikleri görülmektedir. Hiç şüphesiz mesleki yeterlilik ve mimari program akreditasyonu disiplin içinde tutarllık, sürdürülebilirlik ve verimliliği sağlar, ancak; bu makalede önerilen müfredat akreditasyon için başvuru yapılabilecek bir mimarlık programı taslağı olmaktan ziyade kişisel deneyimden yola çıkan ve sezgisel bir manifesto özelliğini de taşıyan bir müfredattır. Önerilen müfredat, mimarlık ve mimarlık eğitim programı alanında interdisipliner, bütünleşik eğitime dayalı yenilikçi modelleri tartışmayı önerir ve mimarlığın disipliner ketumluğunu kırmak yönünde tartısmaya açık alan üretir.

İki yılda bir gerçekleştirilen ve son olarak "Mimarlık, Mesleki Gelişim ve Eğitim Politikaları" temasıyla 13 Aralık 2019 yılında 10'uncusu gerçekleştirilen Mimarlık ve Eğitim Kurultayları, her ne kadar mimarlık ve mimarlık eğitimi alanında bir tartışma ortamı yaratsa da tartışmalarda politik ve mesleki sorunların öne çıktığı görülmektedir. Mimarlık ve Eğitim Kurultayı-VII'de MiAK başkanı Esin sunumunda (Esin, 2014):

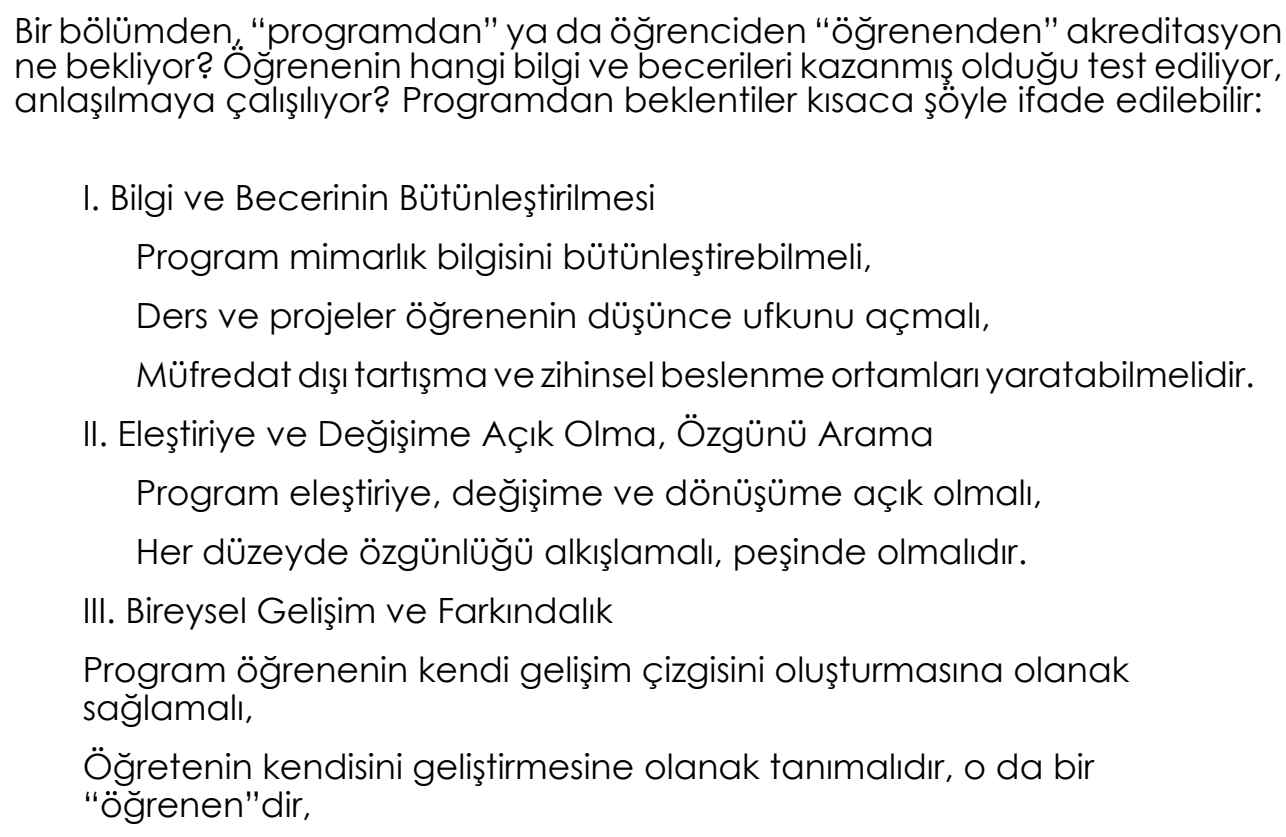

şeklinde bir eğitim programından beklenenleri genel olarak özetlemiştir. Beklentiler, burada önerilen müfredatla gerçekleştirilmeye çalışlan pratiklerle uyumludur. 
Bununla birlikte, mimarlık eğitiminde asgari standart arayışının yanında eğitimin tek tipleşmesinin de önüne geçen bu beklentilerin; kapsamlı ve detaylı bir mimarlık programı üzerinden tartışıması, mimarlık programlarının çeşitlendirilmesi ve farklı programların önerilmesi ile pratiğe dökülmesi mümkündür.

\section{Deneyim (Uygulanan Müfredat)}

Mardin Artuklu Üniversitesi Mimarlık Bölümü, 2006 yllında Dicle Üniversitesi bünyesinde "Mardin Artuklu Mimarlık Fakültesi" adı altında eğitim vermeye ve 2010 yllında üniversitenin sosyal bilimler üniversitesi olma arzusuna paralel bir şekilde disiplinlerarası anlayışı benimseyerek Mardin'de eğitim vermeye başlamıştır. Farklı disiplinlerden gelen akademik kadroya sahip olmasının avantajıyla yenilikçi bir eğitim yaklaşımını hayata geçirerek, mimarlık alanında gelenekselliğin dışına çıkan ders içerikleri ve tasarım olanaklarını desteklemiştir. Nitekim, 2017 yılında, uluslararası saygın mimarlık yapı ödüllerinden olan Mies van der Rohe Ödülü için Türkiye'den eğitiminden ötürü ilk kez yapı dışında aday gösterilmiştir (Bayhan, 2016). Esnek ve disiplinlerarası deneyime olanak sağlayan bu eğitim anlayışı sayesinde, 2019-20 Güz Yarıyıında, 1. Sınıf öğrencilerine verilen kuramsal ve uygulama alanlarındaki Kültür ve Sanat Tarihi'ne Giriş (KSTG) ve Mimari Anlatım Teknikleri (MAT) dersleri bütünleşik yürütülmesi fikri hayata geçirilmiştir. Derslerin mevcut programları esas alınsa da süreç içinde programlar esneyerek parçalanmış, iç içe geçmiş ve alanlar birbirlerini tekrar tekrar yenilemiş, dönüştürmüş ve desteklemiştir. Derslerin etkileşimiyle birlikte her ders sonunda bir sonraki dersin nasıl işlenebileceği öğrencilerle birlikte tartışılmıştır. Haftalık olarak ders konularının uygulama konularıyla bütünleştirilmesi ile Tablo 1 'de gösterilen ders akışı benimsenmiştir.

Tablo 1. iki Dersin Haftalık Bütünleşik Ders Akışı

\begin{tabular}{lll}
\hline HAFTA & $\begin{array}{l}\text { Kültür ve Sanat Tarihine } \\
\text { Giriş }\end{array}$ & Mimari Anlatım Teknikleri \\
\hline $\mathbf{1}$ & Giriş: Kültür, sanat, tarih & $\begin{array}{l}\text { Tesadüfi lekelerin üretilmesi ve kontrollü çizgilerle } \\
\text { denetimleri }\end{array}$ \\
\hline $\mathbf{2}$ & Mağara dönemi & Mağara resmi tarzında leke çalışması \\
\hline $\mathbf{3}$ & Mezopotamya & Stilize soyutlama \\
\hline $\mathbf{4}$ & Mısır & Leke ve kontur \\
\hline $\mathbf{5}$ & Anadolu uygarlıkları & Üç boyutlu formlar \\
\hline $\mathbf{7}$ & Antik Yunan & Perspektif \\
\hline $\mathbf{8}$ & Ara sınav & Dosya teslimi \\
\hline $\mathbf{9}$ & Roma & Perspektif \\
\hline
\end{tabular}




\begin{tabular}{lll}
\hline $\mathbf{1 0}$ & Doğu & Soyut ve figürsel süs \\
\hline $\mathbf{1 1}$ & Rönesans & Perspektif, oranlar ve ışılk gölge \\
\hline $\mathbf{1 2}$ & Aydınlanma & Perspektif, oranlar, şı̈ gölge ve renk \\
\hline $\mathbf{1 3}$ & Modernlik & Modern resimsel anlatım \\
\hline $\mathbf{1 4}$ & Modernlik & Kolaj \\
\hline $\mathbf{1 5}$ & Final & Dosya teslimi \\
\hline
\end{tabular}

1. Hafta: KSTG dersinde kültür, sanat ve tarih genel kavramlarıla birlikte ele alınmış; MAT dersinde ise rastgele renkli lekeler çeşitli yollarla (serpme, damlatma, sürme, dağıtmayla) oluşturulmuş ve leke yorumlama ile lekelerin figürsel çizgilerle denetlendiği bir atölye yapılmıştır.

2. Hafta: KSTG dersi Mardin il merkezdeki İplik Mağaraları'nda yapılmış ve mağara resmi konusu işlenmiş; MAT dersinde ise lekelerle "mağara dönemiyle empati kurduğunuzda bu mağarada nasıl yaşarsınız?" temalı çalışma yapılmıştır.

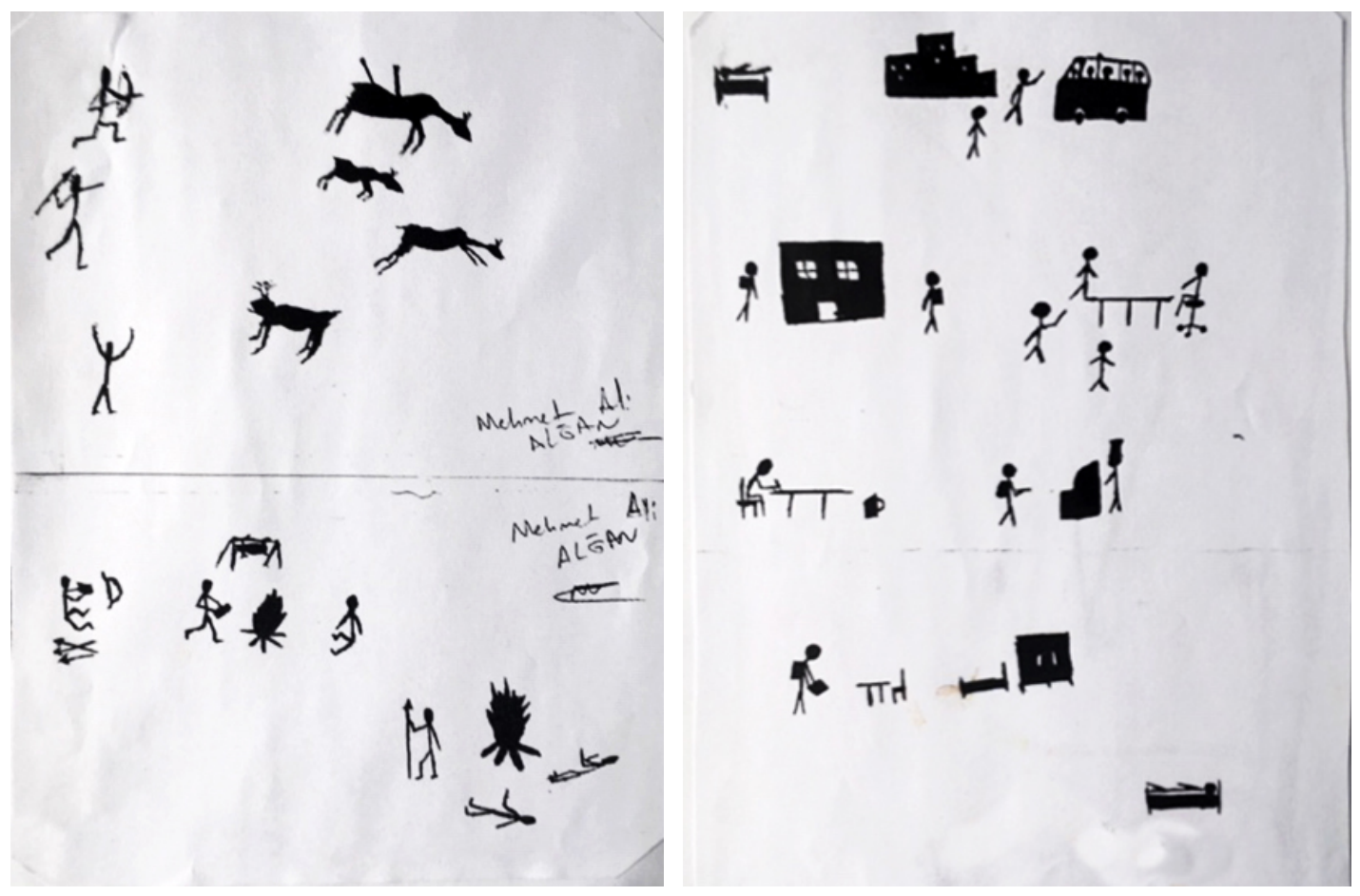

Görsel 1. 2. Hafta MAT'da yapılan çalışma örnekleri

3. Hafta: KSTG dersinde giriş olarak önceki dersin kısa tekrarı ile birlikte MAT dersindeki çalışmalar konuşulmuş, Mezopotamya kültür ve sanatı anlatılmıştır. MAT dersinde ise Mezopotamya sanatındaki stilizasyondan yola çıkılarak dönemle empati kurma temelli soyutlama çalışması yapılmıştır. 
4. Hafta: KSTG dersinde giriş olarak önceki dersin kısa tekrarı ile birlikte MAT dersindeki çalışmalar konuşulmuş, Mısır sanatı ve kurallı Mısır resmi anlatılınıstır. MAT dersinde ise leke ve çizgiden oluşan Mısır sanatı üzerinde konuşulmuş ve dönemle empati temelli leke-çizgi çalışması uygulanmıştır.

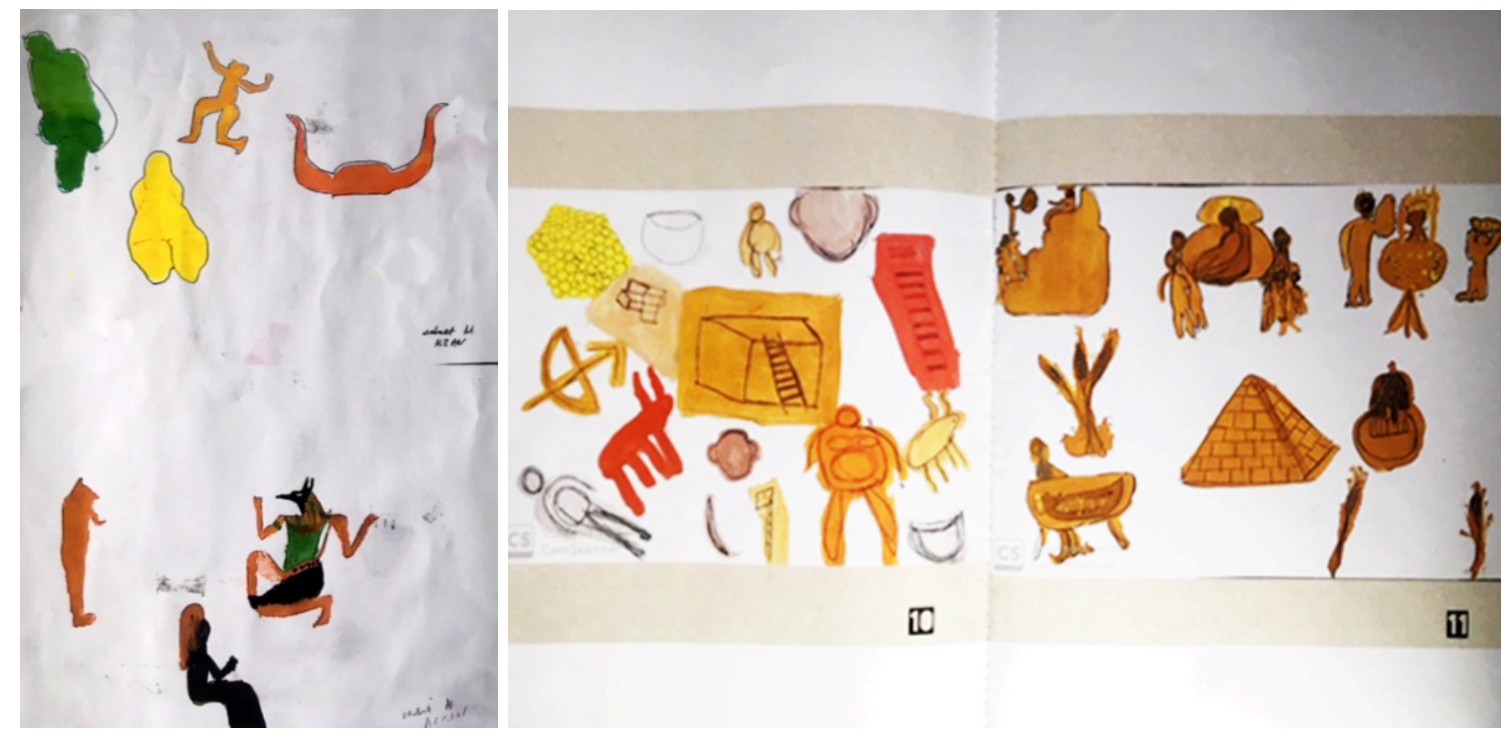

Görsel 2. 4. Hafta MAT'da yapılan çalışma örnekleri

5. Hafta: KSTG dersinde giriş olarak önceki dersin kısa tekrarı yapılmıs, MAT dersindeki çalışmalar değerlendirilmiş, Anadolu uygarlıkları kültür ve sanatı anlatılmıştır. MAT dersinde ise aynı konu konuşulmuş ve dönemle empati kurularak üç boyutlu form tasarımı yapılmıştır.

6. Hafta: KSTG dersinde giriş olarak önceki dersin kısa tekrarı yapılmış, MAT dersindeki çalışmalar konuşulmuş ve Antik Yunan akılcı felsefesi ile sanatı anlatılmıştır. MAT dersinde ise modernliğe kadar sürecek olan akılcı sanatın ilk örnekleri üzerinde durulmuş ve akılcı perspektif uygulama çalışmasına başlanmıştır. 


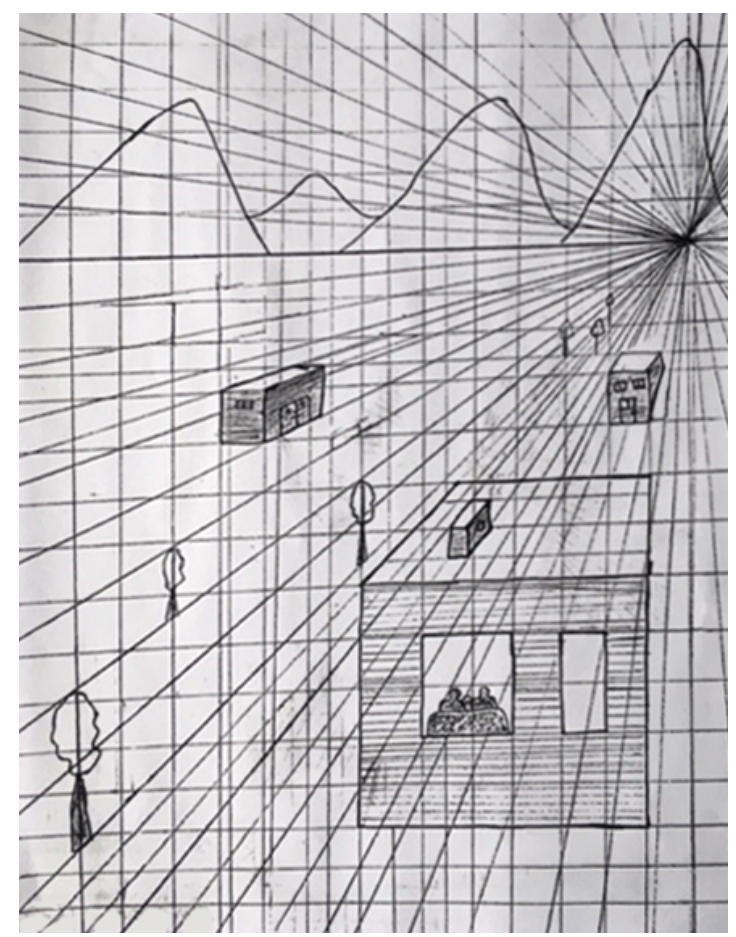

Görsel 3. 6. Hafta MAT'da yapılan çalışma örneği

7. Hafta: KSTG'de ara sınav; MAT'da dosya teslimi.

8. Hafta: KSTG dersinde giriş olarak önceki dersin kısa tekrarı yapılmış, MAT dersindeki çalışmalar konuşulmuş ve Roma akılcı felsefesi ve sanatı (Vitruvius, oranlar ve Roma mühendisliği) anlatılmıştır. MAT dersinde ise Roma dönemi kısaca konuşulmuş ve modernliğe kadar sürecek olan akılcı perspektif ve oranlar çalışmasına devam edilmiştir.

9. Hafta: KSTG dersinde giriş olarak önceki dersin kısa tekrarı yapılmış, MAT dersindeki çalışmalar konuşulmuş ve Ortaçağ kültür ve sanatı (deformasyon ve ifadeci anlatım) anlatılmıştır. MAT dersinde ise Ortaçağ dönemi kısaca konuşulmuş ve figüratif deformasyon ve ifadeci anlatım uygulanmıştır.

10. Hafta: KSTG dersinde giriş olarak önceki dersin kısa tekrarı yapılmış, MAT dersindeki çalışmalar konuşulmuş ve Doğu sanatları (Ortadoğu, Hindistan ve Çin) anlatılmıştır. MAT dersinde Doğu sanatları, özelikle minyatür ve süs üzerine konuşulmuş ve soyut süs uygulaması yapılmıştır. 


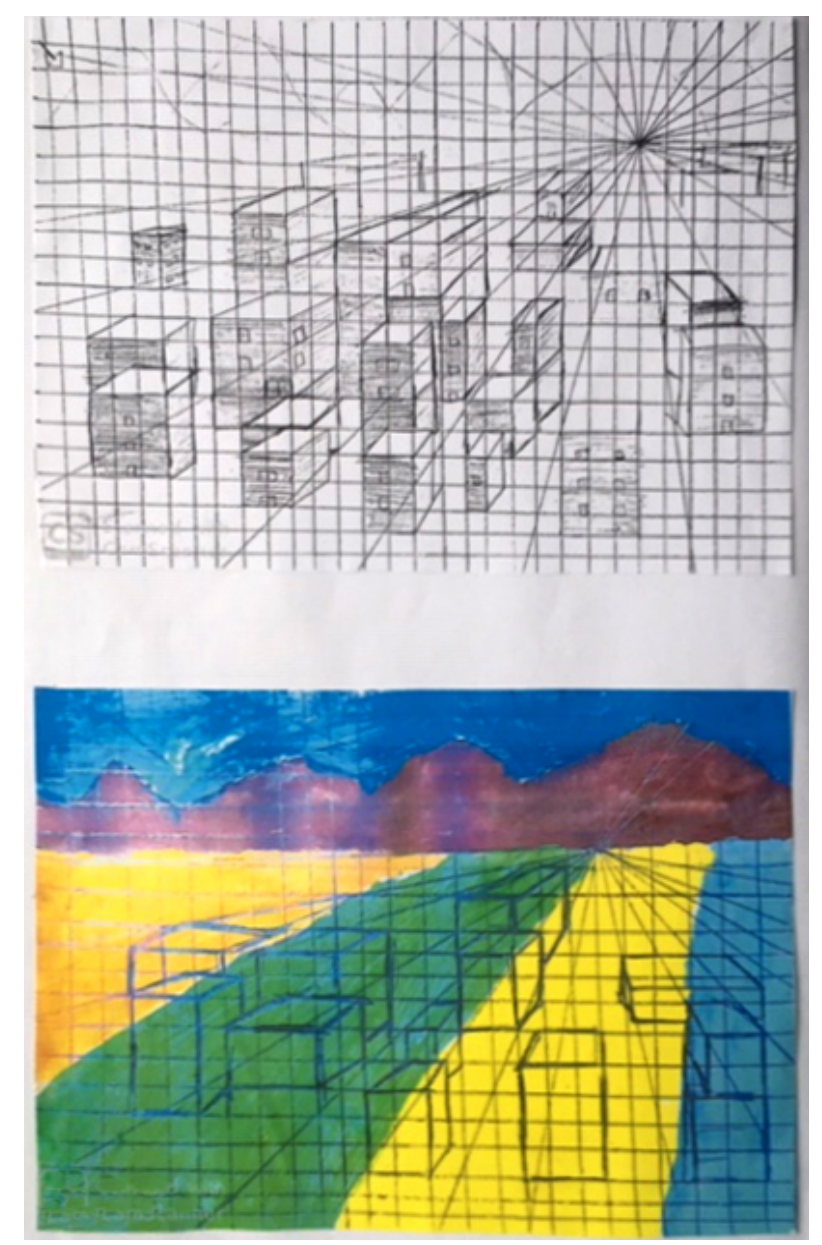

Görsel 4. 11. Hafta MAT'da yapılan çalışma örnekleri

11. Hafta: KSTG dersinde giriş olarak önceki dersin kısa tekrarı yapılmış, MAT dersindeki çalışmalar konuşulmuş ve Rönesans (perspektif, renk, oranlar, ışık gölge) anlatılmıştır. MAT dersinde, Rönesans dönemi kısaca konuşulmuş ve akılcı perspektif ve oranlar ile ışık gölge çalışmasına devam edilmiştir.

12. Hafta: KSTG dersinde giriş olarak önceki dersin kısa tekrarı yapılmış, MAT dersindeki çalışmalar konuşulmuş ve Aydınlanma akılcı felsefesi ile sanatı (klasik sanat) anlatılmıştır. MAT dersinde, aydınlanma dönemi kısaca konuşulmuş ve akılcı perspektif ve oranlar ile ışık gölge ve renk çalışmasına devam edilmiştir. 


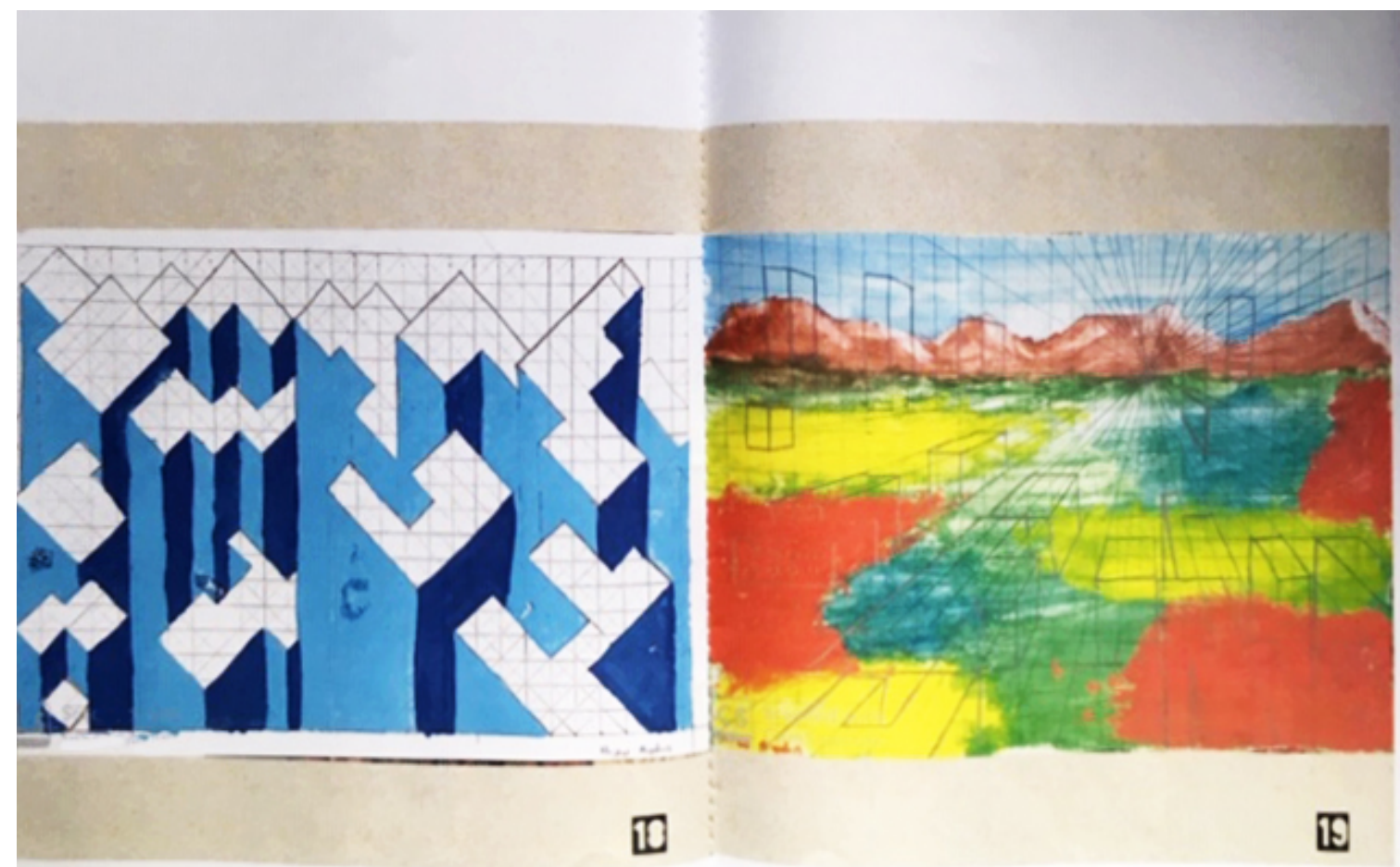

Görsel 5. 12. Hafta MAT'da yapılan çalışma örnekleri

13. Hafta: KSTG dersinde giriş olarak önceki dersin kısa tekrarı yapılmış, MAT dersindeki çalışmalar konuşulmuş ve modernlik ve modern sanat akımları anlatılmıştır. MAT dersinde, serbest renkli modern anlatım uygulaması yapılmıştır.

14. Hafta: KSTG dersinde giriş olarak önceki dersin kısa tekrarı yapılmış, MAT dersindeki çalışmalar konuşulmuş ve modernlik ve modern sanat akımları anlatımıştır. MAT dersinde, serbest renkli kolaj çalışması yapılmıştır. 

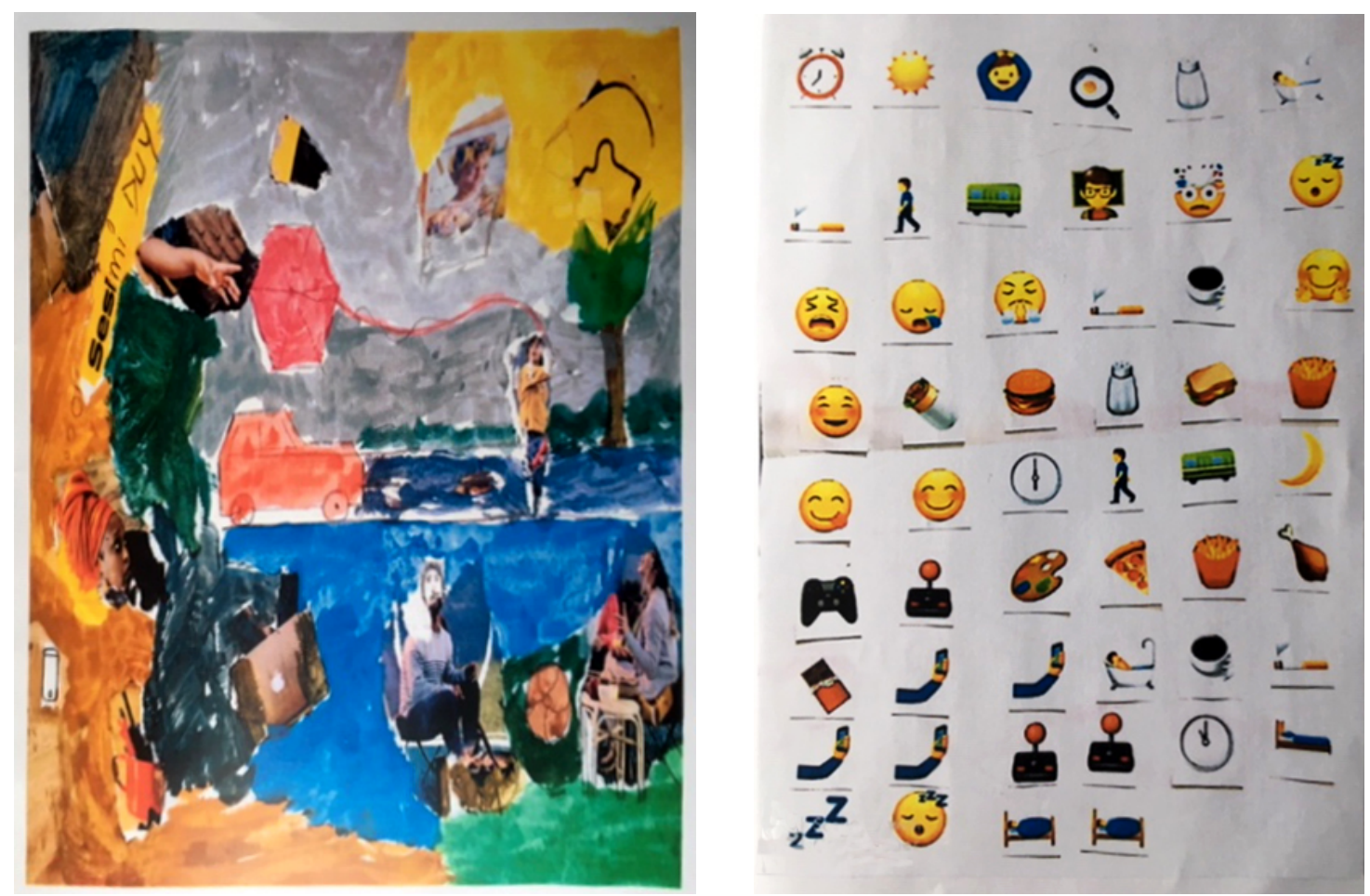

Görsel 6. 14. Hafta(sol) ve 15. Haftadan (sağ) MAT'da yapılan çalışma örnekleri

15. Hafta: KSTG dersinde final sınavı yapılmıştır; MAT dersinde ise güncel anlatım tekniği olarak "emojilerle gündelik yaşamın anlatılması" konulu ödevin yanında dönem boyu yapılan çalışmaların broşür şeklinde tasarlanarak teslim edilmesi istenmiştir.

\section{SONUÇ VE MÜFREDAT ÖNERISI}

Mimari Anlatım Teknikleri dersi ile Kültür ve Sanat Tarihine Giriş dersinin bütünleşik işlenmesi; öğrencilerin her iki derse olan ilgisini artırmış ve daha derin odaklanmalarını sağlamıştır. Derse katıımın ve not ortalamasının yükseldiği, hem ders süresince gözlenmiş hem de dönem sonu değerlendirmesine yansımıştır. Kuramsal konuların uygulamaya uygulamanın da kuramsal konulara geçirgenliği ve dönüşümselliği sayesinde, kuram ve pratik ayrımından ziyade yapıla gelen her şeyin pratikler çoğalması olduğu görülmüştür. Eğitmen ve öğrenci etkileşimini yükseltmiş ve yaratıcı hayal gücünü desteklemiştir. Sınavlarda her iki dersin de birbirini desteklediği ve daha iyi kavrandığı, bilgi ve uygulamanın pekiş̧iği görülmüştür.

Çizgi ve leke çalışmasıyla mağara resminden başlanılması, diğer dönemlerin de kronolojik sıraya göre yürütülmesi ve günümüz iletişim çağı teknolojik diline 


\section{arts}

ulaşılması lineer bir sürece dayansa da, sürekli geri dönüşler ve ilişkisellikler kurularak bilgi ve uygulama pratikleri zenginleştirilmiş, bilgi yanında empatiyle çok yönlü anlama ve zihinsel esneklik desteklenmiştir.

Mimari Anlatım Teknikleri dersi ile Kültür ve Sanat Tarihine Giriş dersi programları esas alınarak tasarlanan ve yürütülen bu deneyim, tasarım derslerinin de bütünleşik eğitim modellemesiyle yürütülmesinin efektif olacağını gösterir niteliktedir. Bu model, Güzel Sanatlar okullarında aydınlanmacı klasik desen eğitimine alternatif veya onunla bileşen bir model olarak görülebilir. Temel tasarımın tarihsel ifade tarzlarıyla birleştirilmesini önerir. Hiç şüphesiz sanatın tarihi temel tasarım bilgisini içermektedir. Burada yapılmak istenen temel tasarım ve modern-postmodern tasarımın tarihsel sürece yayılmasıdır.

Temel tasarım, hem tarihle ve kuramlarla bağları hem de elemanlar/teknik ve fikirler/tasarım anlamında soyuttur ve soyut bir noktadan başlar. Zamanla eğitim ve uygulama anlamında akademik klişelerin üretilmesine yol açmış, yeni gelenekselliklerin oluşması sonucunu doğurmuştur. Bu geleneksellikler geniş anlamda okullarda ya da sanat-mimarlık çevrelerinde klişeleşmeler halinde olabildiği gibi bireysel klişelere de dönüşmüştür ve dönüşme olasılıklarını içinde barındırmaktadır. Geleneksellikler ve klişeler ise zihinsel esnekliği ve tasarımsal yaratıcılığı sınırlayarak her türden pratiğin birlikte ve/veya ayrık olarak nitel farklılaşmasını engeller.

Temel tasarımda; soyut olarak başlayan renk, kontur, leke doku gibi elemanlar üretildikleri zaman, yer ve koşullardan koparımıştır. Bu elemanları yaratıcı biçimde kavramanın yollarından biri ise; ortaya çıkış dönemleri, neden ve nasıl oluşup değiştiklerinin bilgisine sahip olmak, pratiğini kavramak ve insan zihninde yer edişlerini sağlamlaştırmaktır. Geriye dönüşle temel tasarım elemanlarının ortaya çıkış dönem ve koşullarıyla ilişki içinde öğrenilip uygulanması, dönemleri çok yönlü anlamayı da sağlar. Böylece kuram ve uygulama birbirlerini çoğaltıp geri dönüşlerle destekleyerek öğrenilirken, bu ilişkinin esnekliği ve geçirgenliği de zihinsel esnekliği ve yaratıcılığı destekleyen bir özellik kazanır: Dersler birbirlerini desteklemekle kalmaz birbirlerine nüfuz ederler, geri dönüşlerle birbirlerini sağlamlaştıır ve disiplinler arasındaki bu akış disiplinlerarasılık fikrinin kendisinin de özümsenmesi sonucunu ortaya çıkarır. 
Bütünleşik eğitim, kuramsal ve uygulamalı derslerin birbiriyle etkileşimlerinin maksimum düzeye çıkarılarak geçişimli yürütülmesi pratikleri olarak tanımlanabilir. Dersler arasında etkileşim ve geçişimi sağlamak üzere çoklu ders pratikleri, birbirini destekleyecek ve her aşamada değişim esnekliğini de gözetecek şekilde planlanır.

Bütünleşik eğitim modeli, kuram, teknik ve tasarımın birbirleriyle iç içe yürütülmesiyle geçekleşir. Kuramsal derslerde yer alan teknik ve tasarım bilgisinin içerik olarak teknik ve tasarım derslerine nüfuz etmesi, teknik ve tasarım derslerinde yapılanların kuram dersleriyle birlikte dönüşümlü olarak akışması söz konusudur. Kuram, teknik ve tasarım kendi mecralarından ve araçlarından koparımazlar ama çeşitli şekillerde birbirlerine akışları genel veya detay şeylerde olabildiğince çok ve çeşitli olur. Örneğin tarih öğreniminde önemli bir problem olan anakronizm, bütünleşik model içerisinde dönemlere ilişkin empati çalışmaları ile aşılabilir. Bu çalışmaların teknik ve tasarım derslerinde yapılması gerekir ve yaratıcı faaliyetin önemli bir yönü olan empatinin tasarım faaliyeti içindeki yerini sağlamlaştıır.

Lisans düzeyinde eğitim veren mimarlık bölümleri için Tablo 2' de verilen sekiz dönemlik müfredat önerilmektedir. Bu öneride dersler ve konular kuramsal, tasarım ve teknik olarak ayrılmaktadır. Kavramların sözlük taraması sonrası içerik ayrımları şöyle sınıfandırımıştır: "Tasarım 1: Bina, mobilya veya tefrişat gibi işlevsel, grafik veya seri üretim nesnesinin biçimlendirmesi veya işlenmesi, yaratılması ve planlaması. Tasarım 2: Şema; genellikle bir dizi eskiz, belge, çizim, maket veya dijital yollarla bir bina, inşa alanı, yapıt veya nesnenin temsili" (Design, 2008). Mimarlıkta karşıı̆ı olan dersler ise mimari tasarım stüdyolarıdır. "Teknik: Makineler, teknoloji veya uygulamalı bilim ile ilgili. (Technic, 2008). Teknoloji 1: Faydalı bir işlevi yerine getirmek için bilimin pratik kullanımı. Teknoloji 2: Mühendislik bilimleri ve endüstrideki uygulamaları" (Technology, 2008). Mimarlık müfredatındaki karşılığı yapı bilgisi, rölöve, konstrüksiyon ve strüktür ile bilgisayar destekli tasarım, teknik çizim gibi, imaj üretme teknikleridir. Kuramsal ise eğitim literatüründeki kuramsal dersleri kasteder: Kültür ve sanat tarihine giriş, mimarlık tarihi ve bunlarla ilişkilenen felsefi ve sosyolojik kuramları içerir. Bu kavramlar teorik irdelemeden azade, eğitim literatürü açısından ele alınmıştır; teknik, kuramsal ve tasarım ayrımı mimarlık literatürünün disipliner açıdan başat kısımlarını kasteder ve bütünleşik eğitim yaklaşımı da bu üç ana alan arasında işleyebilir. 
Tablo 2. Mimarlık Bölümü için Sekiz Dönemlik Müfredat Önerisi

1. Sinif

1. Dönem:

Kuramsal: Kültür ve sanat tarihine giriş

Felsefe ve sosyolojiye giriş, mimarlık teorisi ve kavramalarına giriş

Tasarım: Mimari tasarım stüdyosu: Kuramsal içerikle ilişkilenen projeler

Teknik: Mimari anlatım teknikleri: Kuramsal içerikle ve temel tasarım stüdyosuyla ilişkilenen teknikler

\section{Dönem:}

Kuramsal: Doğal toplumlarda mimari, din, büyü, sanat, efsane

Tasarım: Doğal yapı ve ilksel mimari içerikli proje (doğal toplumlara ilişkin empati çalışmalarını da kapsar)

Teknik: Doğal toplumlarda yapılar ve ilksel mimarilerde teknik

Bilgisayar destekli tasarıma giriş

2. Sinif

\section{Dönem}

Kuramsal: Mezopotamya ve Mısır mimarlığı, mitoloji ve kutsal anlatı

Tasarım: Mezopotamya ve Mısır'dan yola çıkan stilizasyon ve soyutlama içerikli mimari proje

Teknik: Tuğla yapı ve sütunlu taş yapı

Bilgisayar destekli tasarım

\section{Dönem}

Kuramsal: Antik Yunan ve Roma dönemi mimarlığı, ilkçağ düşüncesi

Tasarım: Antik Yunan ve Roma içerikli mimari proje

Teknik: Taş yapı, sütun, kemer, kubbe, tonoz, kubbe Bilgisayar destekli tasarım

3. Sinif

\section{Dönem}

Kuramsal: Batı Ortaçağı ve İslam Mimarlığı, Ortaçağ toplumsallığı ve düşüncesi

Tasarım: Batı Ortaçağı ve İslam Mimarlığı, Ortaçağ toplumsallığı ve düşüncesi içerikli

mimari proje

Teknik: Ifadeci taş yapı, sütun, kemer, tonoz, kubbe, süsleme

\section{Dönem}

Kuramsal: Rönesans ve Aydınlanma'dan Modernliğe mimarlık tarihi, Rönesans ve

Aydınlanma düşüncesinden modernlik düşüncesine

Tasarım: Modern yapı projesi

Teknik: Rölöve, konstrüksiyon

4. Sinıf

7. Dönem

Kuramsal: Modern mimarlık tarihi, çağdaş sosyal teori, modern sanat akımları

Tasarım: Modern mimari proje

Teknik: Rölöve, konstrüksiyon

\section{Dönem}

Kuramsal: Güncel mimarlıklar, güncel teoriler, güncel sanat

Tasarım: Güncel mimari bitirme projesi

Bu müfredat önerisinde önemli olan, kuram ve uygulama eğitmenlerinin çeşitli tarzlarda birlikte çalışmasıdır. Eğitmenler dönemlik ders planlarını iletişim içinde hazılar, birbirlerinin derslerinin programlarını takip eder ve/veya katıır, birbirleriyle ve 
öğrenciyle iletişir ve gerektiğinde kuram, tasarım ve teknik konularında ortak ders yaparlar. Öğrenci her derste bir diğer dersi de düşünür ve irdeler. Dersler arasındaki analitik bağları kavrama düzeyi artar. Tasarım projelerini edindikleri kuramsal, teknik ve tasarımsal arkaplanla yaparlar. Kuram derslerinde geri dönüşler sayesinde dersler arasında çok yönlü akışlar gerçekleşir. Öğrencinin teknik bilgisi pekişir, kavrayışı çok yönlü olarak bütünselleşir ve güçlenir. Örneğin Antik Roma döneminde ve Ortaçağ'da kemer-kubbe-tonoz sistemini öğrenen bir mimarlık öğrencisinin malzeme ve taşıyıcılık bilgisi pratikleşir. Rönesans'ta klasik resim çalışan öğrencinin anatomi, oran ve kompozisyon bilgisi pekişir. Bütünleşik müfredat programında eğitmenlerin iş yükleri ve performansları aynı anda yükselir. Tarihsel dönemlere göre yapılan stüdyolarda, konuların kısıtlanması ise bu modellemenin dezavantajlı tarafı olarak görülebilir.

Bu müfredatta kuramsal, teknik dersler ve stüdyoların eşgüdümlü yürütülmesi mümkün olur/yürütülmelidir. Kuramsal, tasarım ve teknik alanlarından eğiticiler her dönem birlikte çalışmalı, aynı programın bileşenleri olarak eğitimin akışına göre programın senkronizasyonunu sağlamalıdır.

Tarihsel dönemselliklerde kuram, teknik ve tasarım birbiriyle bütünlük arz eder. Derslerde kuram, teknik ve tasarımların ortaya çıktıkları dönemselliğin incelenmesi ve o döneme ilişkin empati temelli çalışmalar yapılması esastır. Bu şekilde kuram, teknik ve tasarım bütünleşik olarak her türden pratiğe dökülebilir; kuram, teknik ve tasarım dersleri arasındaki kopukluklar giderilir. Tarihsel dönemselliklerin ele alınmasında bu yaklaşımın benimsenmesi, mimarlıktaki yapı bilgisi ve restorasyon bilgisine ilişkin birikimi de canlandırır, dönüştürür. Öğrenci, her tarihsel dönem için çalışırken ve tekrar yeni tasarımlar yaparken kendi bilgi ve tasarım pratiğini de oluşturur.

Bu müfredat önerisi hiç şüphesiz uygulamada revize edilmeye açıktır ve üzerinde tartışılması gereken ders içeriklerinin ana hatları ile verildiği manifest bir modellemedir. Mimarlık kuramı ve eğitimi üzerine yazım ve uygulama pratiği özelliği taşır. Bu yönüyle mimarlık programı değil, deneyim üzerinden önerilen müfredattır ve mimarlık eğitiminde yeni ve farklı bir mizansene çağrıda bulunur. Bu mizansenin oluşturulmasında avangart akımların deneyimlerinin yeniden hatırlanması kuşkusuz önemlidir. Mimarlık alanında avangart akımların önemini Tanju şöyle değerlendirir 


\title{
arts $s$
}

(Tanju, 2003, s. 57):

\begin{abstract}
Avangart genellikle kabullenilenin aksine, kimi egosantrik öznelerin uçuk kaçık etkinliklerinin çok ötesinde anlam taşıyor. Organik, rasyonel ya da sentetik, her türlü bütünsellik/birlik nostaljilerinin; gerçekliğin tek ve doğru temsiline dayanan uzlaşma arayışlarının kaçınılmaz bir terör içerdiğini fark etmek gerekiyor, tıpkı vücüttaki sıvı dolaşımının yol açtığına benzer bir terör. Eğer mimarlığın, teknokratik eylemlerin ve moda üretiminin dışında, hala anlamlı olma gizilgücü varsa, bunu ancak etkin farkllıkların üzerinden işleyen bir deneysellikle gündeme getirmesi gerekiyor.
\end{abstract}

Makale kapsamında değinilen akreditasyon kuruluşlarının niyet olarak önerdikleri ancak pratikte standartlaşmaya da yol açan destek ve denetim süreçleri, sanat, mühendislik ve mimarlık alanlarını bir araya getirerek farklılık ve yaratıcılıktan beslenen Bauhaus ve Konstrüktivizm gibi avantgart akımların hayat ve eğitim üzerinden deneyimledikleri süreçlerden farklı bir mecrayı temsil eder. Bu mecradan hareket eden her türden mimarlık pratiği yeni tartışmaların önünü açar, disipline hapsolmuş pratiklerin ilişkiselliğinin yaratıcı üretimler için elzem olduğunu hatırlatır.

\section{KAYNAKÇA}

Akgün, Y. (2016). Bütünleş-ik Mimarlık Eğitimi ve Pratiği. Ege Mimarlık Dosya, 93.

Antmen, A. (2010). 20.Yüzyıl Batı Sanatında Akımlar. İstanbul: Sel.

Bayer, H., Gropius W. ve Gropius I. (ed. ). (1938). Bauhaus, 1919-1928. New York: 1. The Museum of Modern Art. https://www.moma.org/documents/moma_ catalogue_2735_300190238.pdf

Bayhan, B. (2016, 22 Aralık). 2017 Mies Ödülü'ne Türkiye'den 13 Proje Aday Gösterildi. Arkitera. https://www.arkitera.com/haber/2017-mies-oduluneturkiyeden-13-proje-aday-gosterildi/. Erişim Tarihi: 13 Şubat 2021.

Conrads, U. (1991). 20.Yüzyıl Mimarisinde Program ve Manifestolar. (Çev. Dr. S. Yavuz). İstanbul: Şevki Vanlı Mimarlık Vakfı.

Design (2008). N. Davies ve E. Jokiniemi (Ed) Dictionary of Architecture and Building Construction (s. 112). USA: Architectural Press is an imprint of Elsevier.

EAAE, About EAAE. https://www.eaae.be . Erişim Tarihi: 13 Şubat 2021

Esin, N. (2014). Mimarlık Eğitiminde Akreditasyon Tartışmalı Konular Üzerinde 
Yeniden Düşünelim. Mimarlık Dergisi, 376.

Gropius, W. (1965). The New Architecture and the Bauhaus. (Çev. P. M. Shand). Cambridge: M.I.T.

Jacobs, H. H. (Ed.). (1989), Interdisciplinary Curriculum: Design and Implementations. USA Alexandria: Edwards Brothers Inc.

MiAK. Mimarlık Akreditasyon Kurulu Çalışma Esasları 2017. http://miak.org. Erişim Tarihi: 13 Şubat 2021

MiAK. MiAK Başvurulu Mimarlık Programları ve Süreçleri. http://miak.org/ index.cfm?sayfa=okullar. Erişim Tarihi: 13 Şubat 2021.

NAAB. Histoy. https://www.naab.org. Erişim Tarihi: 13 Şubat 2021

Said, E. W. (1983). The World, The Text and The Critic. Cambridge, Massachusetts: Harvard UP.

Stevens, G. (2014). A History of Architectural Education in the West 2001. http://www.archsoc.com/kcas/Historyed.html.

Sözen, M. ve Tanyeli, U. (2011). Sanat Kavram ve Terimleri Sözlüğü. İstanbul: Remzi.

Tanju, B. (2003). Avangart Hemen Şimdi!. Arredamento Mimarlık. 155, 57-58.

Technic (2008). N. Davies ve E. Jokiniemi (Ed) Dictionary of Architecture and Building Construction (s. 376). USA: Architectural Press is an imprint of Elsevier.

Technology (2008). N. Davies ve E. Jokiniemi (Ed) Dictionary of Architecture and Building Construction (s. 376). USA: Architectural Press is an imprint of Elsevier. 